\title{
REPRODUCTIVE PHYSIOLOGY OF THE STALLION
}

\section{SPERMATOGENESIS AND TESTIS COMPOSITION}

\author{
E. E. SWIERSTRA,* M. R. GEbAUER AND B. W. PICKETT \\ Department of Physiology and Biophysics, Colorado State University, \\ Fort Collins, Colorado 80521, U.S.A., and \\ *Agriculture Canada, Research Station, Brandon, Manitoba, Canada
}

(Received 31st Fanuary 1974)

Summary. The cycle of the seminiferous epithelium of the stallion was divided into eight stages, using as criteria the presence of meiotic divisions, shape of the spermatid nuclei and location of spermatids with elongated nuclei in the tubule. The mean frequencies of stages 1 to 8 were $16.9,14.9,3.2,15 \cdot 8,7 \cdot 4,13.5,12.6$ and $15.7 \%$, respectively. The duration of one cycle of the seminiferous epithelium was 12.2 days (S.E. $\pm 0 \cdot 1$ ) as determined by injecting a single dose of $700 \mu \mathrm{Ci}$ of $\left[{ }^{3} \mathrm{H}\right]$ thymidine into each spermatic artery of six stallions and removing testes at different intervals after the isotope injection. The life-span of primary spermatocytes was 19.0 days, secondary spermatocytes 0.7 days, spermatids with round nuclei 8.7 days, and spermatids with elongated nuclei $10 \cdot 1$ days. Radioactive spermatozoa were observed in the caput epididymidis 35 days after $\left[{ }^{3} \mathrm{H}\right]$ thymidine injection. The volumetric percentages of testicular components were: spermatogonial nuclei, $0 \cdot 6$; primary spermatocyte nuclei, $4 \cdot 2$; secondary spermatocyte nuclei, $0 \cdot 1$; round spermatid nuclei, $2 \cdot 1$; elongated spermatid nuclei, 1.0; Sertoli cell nuclei, 1.6; tubular cytoplasm, 45.7; lumina, 3.4; basement membranes, 2.6; and intertubular spaces, 38.7\%. The seminiferous tubules made up $61.3 \%$ of the testicular volume. The diameters of the seminiferous tubules varied significantly among stallions, but not among stages. The average length of the seminiferous tubules per testis was $2419 \mathrm{~m}$ (range 1667 to $3726 \mathrm{~m}$ ).

\section{INTRODUGTION}

In sexually mature males, the spermatogenic cells are organized in welldefined cellular associations (stages) which succeed one another in any given area with the passage of time. A complete sequence of stages up to the reappearance of the first at a given point constitutes one cycle of the seminiferous epithelium (Roosen-Runge \& Giesel, 1950; Leblond \& Clermont, 1952). The cycle of the seminiferous epithelium of various mammals was recently reviewed by Clermont (1972). The duration of the cycle varies among species, but appears to be relatively constant for a given species. The structural composition of the testes of mature animals also varies among species (Bascom \& 
Osterud, 1925; Kennelly \& Foote, 1964; Swierstra, 1966) and is influenced by the time of year in seasonal breeders (Gier \& Marion, 1970). In the stallion, season is known to influence seminal characteristics and sexual behaviour (Nishikawa, 1959; Skinner \& Bowen, 1968; Pickett, Faulkner \& Sutherland, 1970). Since, however, there appears to be little detailed quantitative information on spermatogenesis in the stallion (Masui, 1919), a system for classifying stages of the cycle of the equine seminiferous epithelium was developed and utilized to establish their relative frequency, the absolute duration of the cycle, and the influence of season upon the structural composition of the testes.

\section{MATERIALS AND METHODS}

\section{Experimental stallions and $\left[{ }^{3} \mathrm{H}\right]$ thymidine injection procedure}

Two groups of six mature stallions each were used to study the cycle of the seminiferous epithelium and the structural composition of the testes. The two groups of stallions were killed at different times of the year (September and December), but the results were combined (Exp. 1) since the two groups did not differ significantly as to the frequency of the stages and the structural composition of the testes except for percentage of primary spermatocyte nuclei. The stallions ranged in age from 3 to 10 years and had a mean body weight of $473 \mathrm{~kg}$ (S.D. \pm 54 ).

An additional group of six stallions averaging $456 \mathrm{~kg}$ (S.D. \pm 76 ) in body weight and ranging in age from 2 to 13 years were used to determine the duration of spermatogenesis by administration of $\left[{ }^{3} \mathrm{H}\right]$ thymidine (Exp. 2). Before isotope injection or castration, the stallions were tranquillized with Acepromazine, and anaesthesia was induced by intravenous injection of thiamylal sodium followed by closed-circuit administration of halothane and oxygen. For the isotope injections, the line of incision extended from just posterior to the inguinal ring towards the testis, the spermatic artery was exposed and a single intra-arterial dose of $700 \mu \mathrm{Ci}\left[{ }^{3} \mathrm{H}\right]$ thymidine (specific activity 18.4 or $20.1 \mathrm{Ci} / \mathrm{mmol}$ ) was injected. An interval of about $40 \mathrm{~min}$

\section{EXPLANATION OF PLATES 1 AND 2}

FIGS 1 to 8 are photomicrographs of partial cross-sections of stallion seminiferous tubules representative of stages 1 to 8 , respectively. Periodic acid-Schiff-haematoxylin stain. $\times 720$.

Figs 9 to 11 are photomicrographs of autoradiographs of stallion testes removed $4 \frac{1}{2}$ hr, 9 days and 35 days, respectively, after $\left[{ }^{3} \mathrm{H}\right]$ thymidine injection. Arrows indicate the most advanced labelled germinal cells at the different intervals after injection. Feulgenhaematoxylin stain. $\times 720$.

$\mathbf{A}=$ type A spermatogonia $\mathbf{B}=$ type $\mathbf{B}$ spermatogonia $\mathbf{C}=$ Sertoli cells $; \mathrm{D}=$ basement membranes; $\mathbf{E}=$ younger generation of primary spermatocytes; $\mathbf{F}=$ older generation of primary spermatocytes; $\mathbf{P}=$ secondary spermatocytes; $\mathbf{R}=$ spermatids with round nuclei; $\mathbf{S}=$ spermatids with elongated nuclei.

FIG. 9. Tubule $4 \frac{1}{2} \mathrm{hr}$ after injection; stage 1 . Leptotene primary spermatocytes in stage 1 were the most advanced labelled germinal cells.

FIG. 10. Tubule 9 days after injection; stage 8 . Pachytene primary spermatocytes in stage 8 were the most advanced labelled germinal cells.

Frg. 11. Tubule 35 days after injection; stage 8. Labelled elongated spermatids lining the lumen of the tubule. Two cycles of the seminiferous epithelium later than in Fig. 10.

Fic. 12. Tubule 35 days after injection. Some labelled spermatozoa were present in the caput epididymidis. Feulgen stain. $\times 720$. 


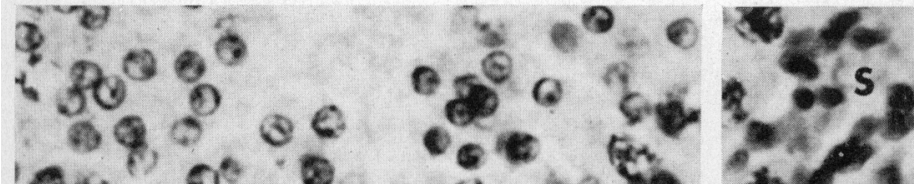

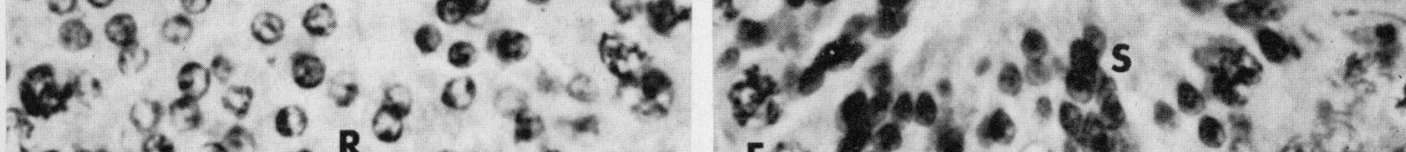

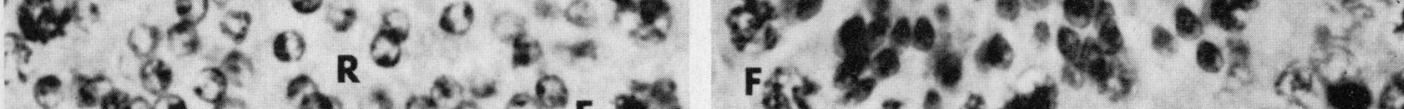

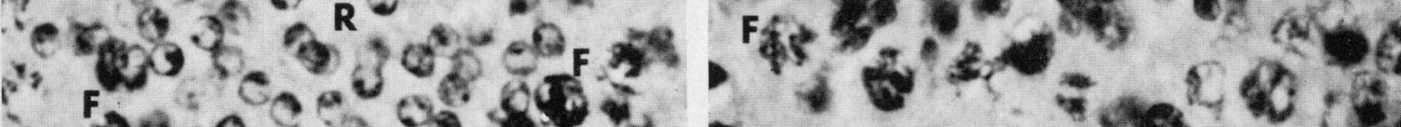

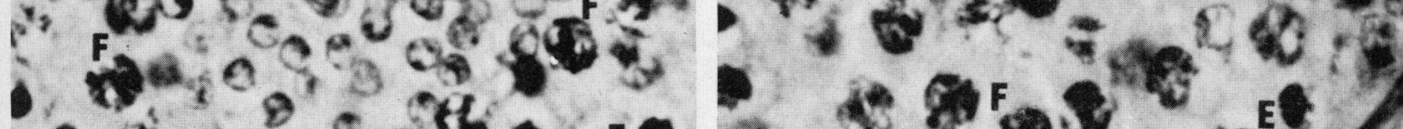

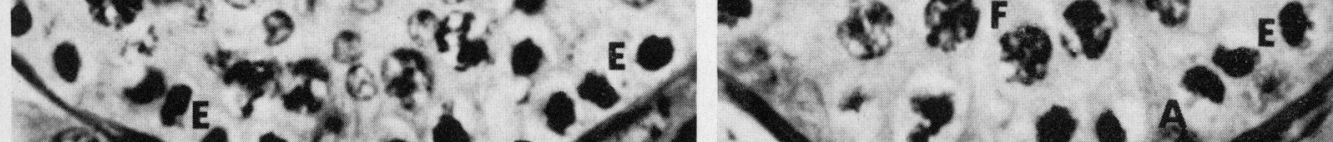
120000 2 D

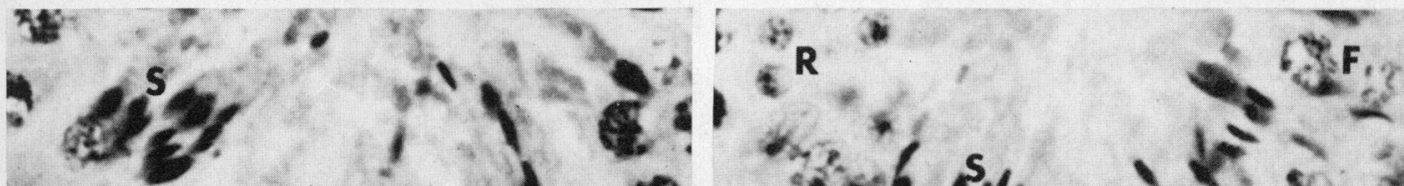

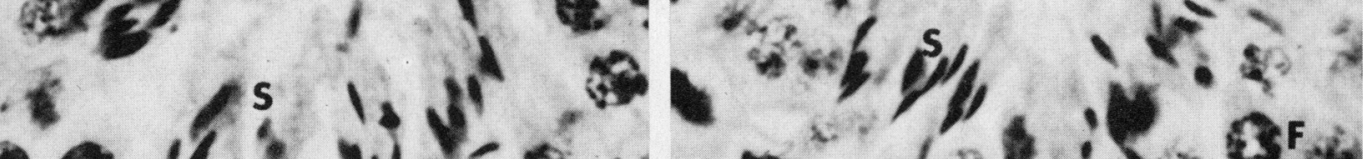

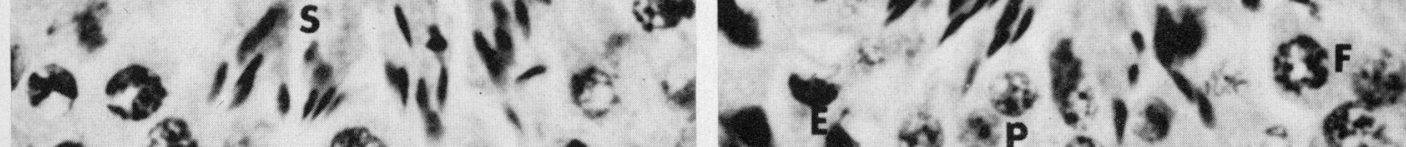

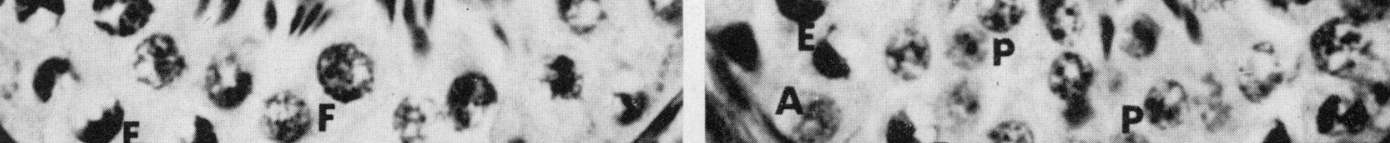

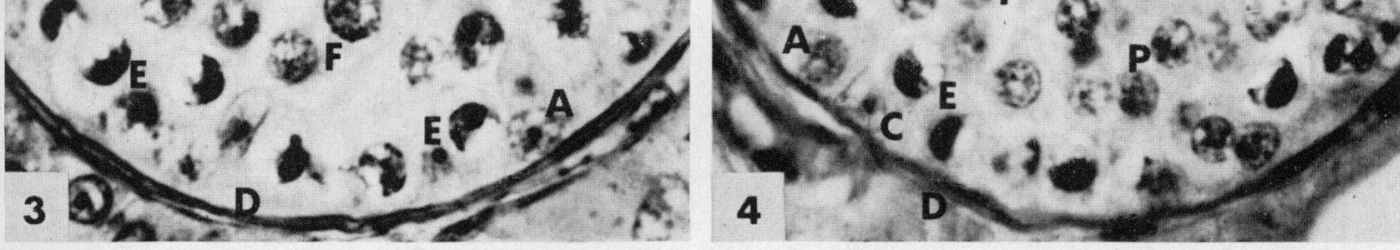

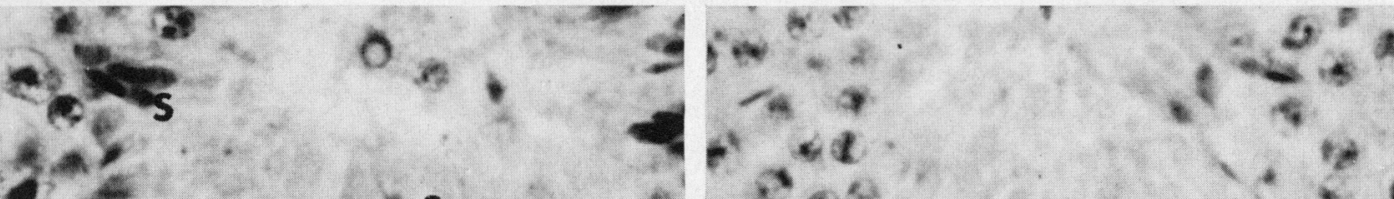

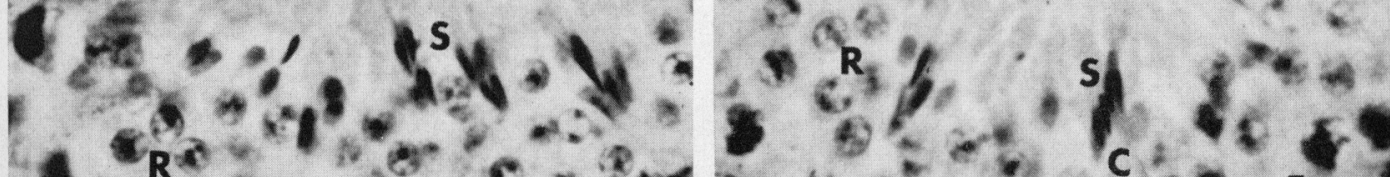

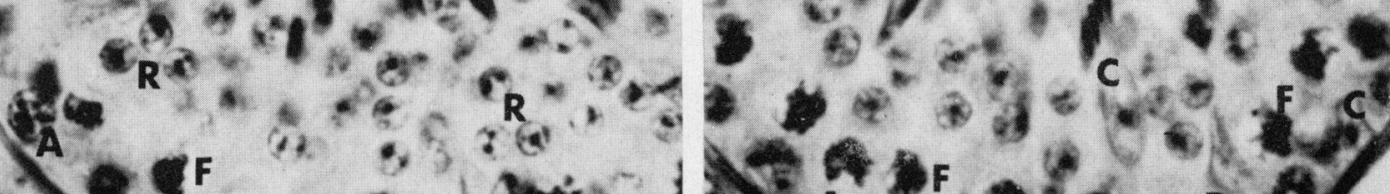
$5 \sin ^{\circ}$ a T A 


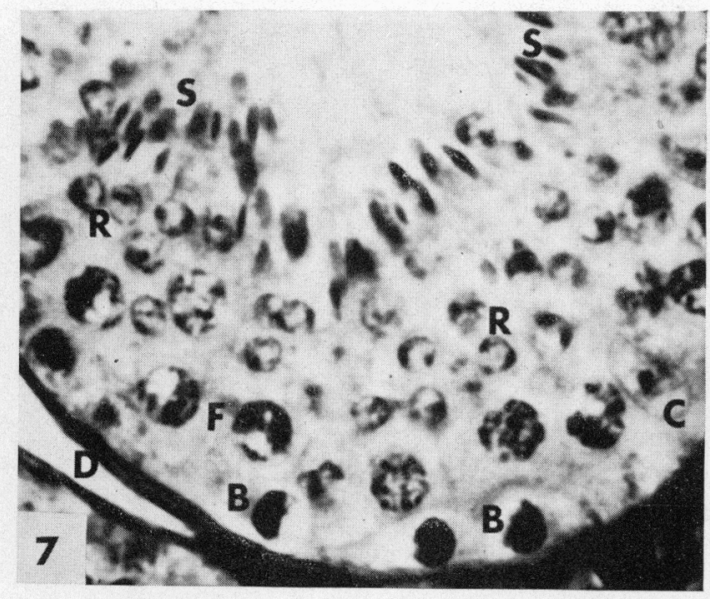

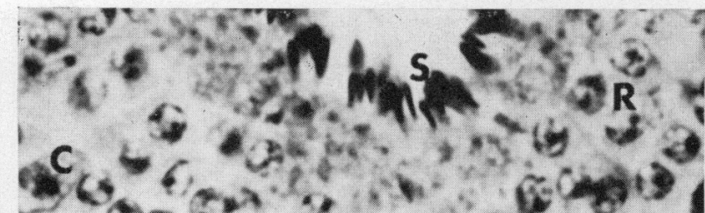
Le

$3 x^{2}=0$

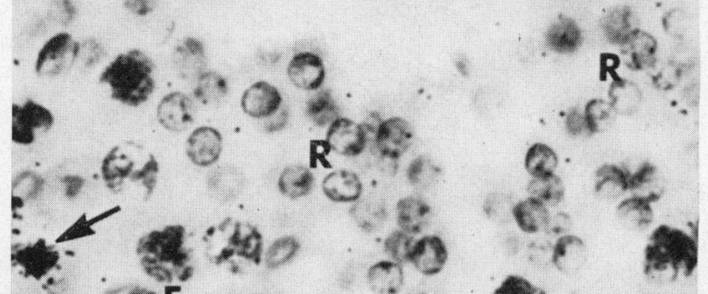

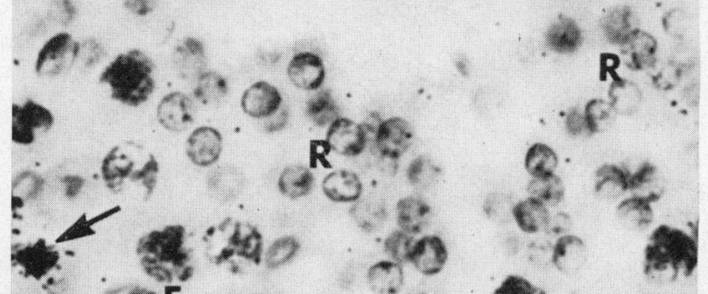

EF E a d 0

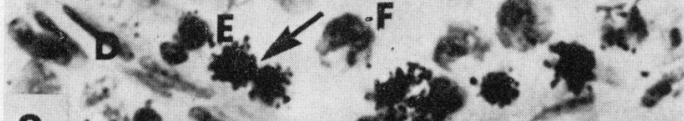

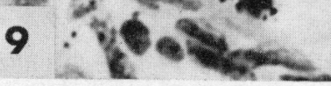

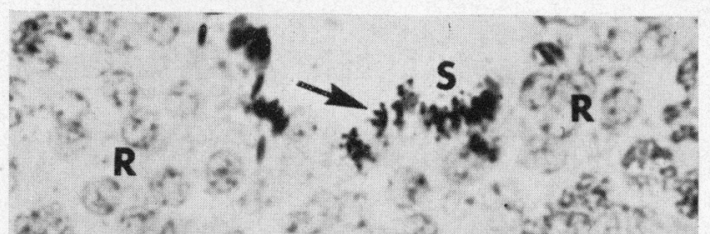

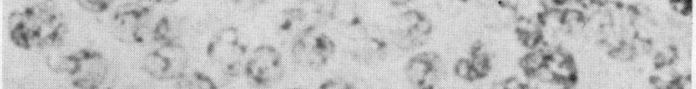

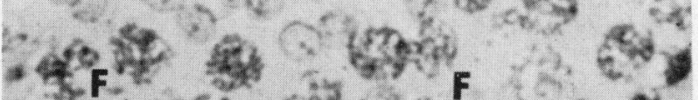

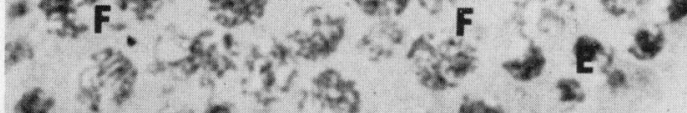

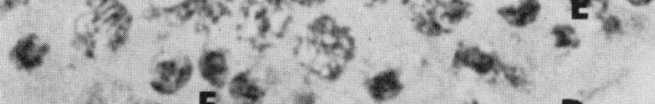

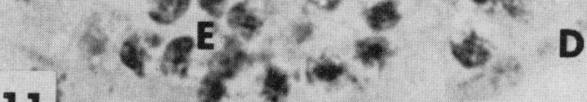
1116 
separated the two injections for each animal. Unilateral castrations were performed $4 \frac{1}{2} \mathrm{hr}$ and $9,17,18,25,30$, and 35 days after the injections.

Testicular, epididymal and tunica albuginea weights were recorded for all stallions.

\section{Cycle of the seminiferous epithelium}

The cycle of the seminiferous epithelium was divided into eight stages, based on the morphology and cytology of the germinal cells and their relative positions within the seminiferous tubule (Roosen-Runge \& Giesel, 1950; Swierstra, 1968a; Ortavant, Courot \& Hochereau, 1969; Foote, Swierstra \& Hunt, 1972).

Stage 1. From the complete disappearance of luminal spermatozoa to the onset of elongation of the spermatid nuclei (Pl. 1, Fig. 1).

Stage 2. From the onset of elongation to the end of elongation of the spermatid nuclei (Pl. 1, Fig. 2).

Stage 3. From the end of elongation of the spermatid nuclei to the start of the first meiotic division (Pl. 1, Fig. 3).

Stage 4. From the start of the first to the end of the second meiotic (maturation) division (Pl. 1, Fig. 4).

Stage 5. From the end of the second meiotic division to the initial appearance of type B spermatogonia (Pl. 1, Fig. 5).

Stage 6. From the initial appearance of type B spermatogonia to the time all bundles of elongated spermatids have started migration toward the lumen of the seminiferous tubule (P1. 1, Fig. 6).

Stage 7. From the time all bundles of elongated spermatids have started their migration toward the tubular lumen until they all reach the lumen (Pl. 2, Fig. 7).

Stage 8. From the time the elongated spermatids line the lumen to their complete disappearance from the lumen (PI. 2, Fig. 8).

The relative frequency of the stages was determined by classifying fifty randomly selected tubular cross-sections in each of two histological sections from three locations of the testes of stallions in Exp. 1. This provided 300 classified tubular cross-sections per testis, for a total of 7200 . In the stallions injected with the isotope (Exp. 2), the frequency of stages was determined by classifying fifty randomly selected tubular cross-sections with normal cell populations in one histological section from each of the three locations per testis. Before analyses of the frequency of the stages, all percentages were transformed to arcsin.

The frequency of the stages expressed as a percentage of the total classified was used to calculate the duration of each stage. The duration of one cycle of the seminiferous epithelium was determined by measuring how far labelled germinal cells had progressed at various intervals after $\left[{ }^{3} \mathrm{H}\right]$ thymidine injection (Swierstra, 1968a; Clermont, 1972). In each case, the autoradiographs were systematically analysed, and the location of the most advanced labelled germinal cell was recorded.

\section{Testicular composition}

The method of Chalkley (1943) was used to determine the volume of the 
different cell types and other components of the testes of the stallions in Exp. 1 . A graticule (Merz graticule by Wild) was placed in one of the eyepieces of a binocular microscope, and observations were made at $\times 1000$. Twelve structures in each of seventy randomly selected fields at each of three locations were recorded, for a total of 2520 observations per testis. Testicular elements were classified as spermatogonial nuclei, primary spermatocyte nuclei, secondary spermatocyte nuclei, round spermatid nuclei, elongated spermatid nuclei, Sertoli cell nuclei, tubular cytoplasm, lumen, basement membrane, and intertubular space. The non-nuclear area within the tubule stained by the Periodic acid-Schiff (PAS)-haem technique was classified as tubular cytoplasm. All percentages were transformed to arcsin before statistical analysis.

\section{Tubular diameters and tubular lengths}

In Exp. 1, tubular diameters were determined by measuring twenty-four seminiferous tubules (twelve stallions $\times$ two tubules) per stage of the seminiferous epithelium. Each tubule was measured at right angles with a filar micrometer and the two values were averaged. The length of the seminiferous tubules was calculated for the testes of all stallions in Exp. 1, taking into account testicular weight, tunica albuginea weight, testicular density, shrinkage due to histological processing, the volume percentage of tubules in each testis, and the tubular diameter (Swierstra, 1966). The testicular density was 1.04, and the shrinkage due to histological processing was $43 \%$ of the volume (Gebauer, 1973).

\section{Histology and autoradiography}

Testicular samples were taken near to the caput epididymidis, and the cauda epididymidis and midway between the poles. One piece of tissue was removed from each location of the testes of stallions in Exp. 1. Two pieces were taken from each location of the testes of stallions in Exp. 2. Tissue samples were fixed in Allen's fixative (Gray, 1958) and processed by routine methods. Tissue sections for quantitative histology were stained by the PAS-haem technique; those for autoradiography were stained by the Feulgen technique before coating with Kodak NTB-3 Nuclear Tract Emulsion. In addition, seminal smears were prepared from the caput epididymidis removed 35 days after the isotopic injection and coated with emulsion. The coating was done with a stainless steel roller. The slides were dried in air, placed in light-excluding plastic boxes that contained a small bag of $\mathrm{CaSO}_{4}$, and stored at $5^{\circ} \mathrm{C}$. Replicates of these slides were exposed for 12 or 20 weeks and developed and fixed at $5^{\circ} \mathrm{C}$ (Bélanger, 1961). The autoradiographs were restained, using Mayer's haematoxylin, before placing coverslips on the slides.

\section{RESULTS}

\section{Cycle of the seminiferous epithelium}

The relative frequencies of the eight stages of the cycle were not significantly different for the two groups of stallions killed at different times of the year (Exp. 1) and the results were combined (Table 1). Stallions differed significantly 
with respect to the frequencies of certain stages, but frequencies were similar between testes of each stallion and among the three locations within a testis.

For the stallions injected with $\left[{ }^{3} \mathrm{H}\right]$ thymidine (Exp. 2), the relative frequencies of stages 1 to 8 were $17 \cdot 0,15 \cdot 3,2 \cdot 9,16 \cdot 0,7 \cdot 3,11 \cdot 9,13 \cdot 0$ and $16 \cdot 5 \%$, respectively. These frequencies were similar to those found in Exp. 1, for control stallions (Table 1).

Table 1. Relative frequency and mean duration of the stages of the cycle of the seminiferous epithelium in stallions (Exp. 1)

\begin{tabular}{|c|c|c|c|c|c|c|c|c|}
\hline \multirow{2}{*}{ Characteristic } & \multicolumn{8}{|c|}{ Stage of the cycle of the seminiferous epithelium } \\
\hline & 1 & 2 & 3 & 4 & 5 & 6 & 7 & 8 \\
\hline Frequency* $(\%)$ & $\begin{array}{r}16.9 \\
\pm 0.4\end{array}$ & $\begin{array}{r}14.9 \\
\pm 0.4\end{array}$ & $\begin{array}{r}3.2 \\
\pm 0.2\end{array}$ & $\begin{array}{r}15.8 \\
\pm 0.4\end{array}$ & $\begin{array}{r}7.4 \\
\pm 0.4\end{array}$ & $\begin{array}{r}13.5 \\
\pm 0.5\end{array}$ & $\begin{array}{r}12.6 \\
\pm 0.6\end{array}$ & $\begin{array}{r}15.7 \\
\pm 0.5\end{array}$ \\
\hline Duration (days) & $2 \cdot 1$ & 1.8 & 0.4 & 1.9 & 0.9 & 1.6 & 1.5 & 1.9 \\
\hline
\end{tabular}

* Mean \pm S.E.

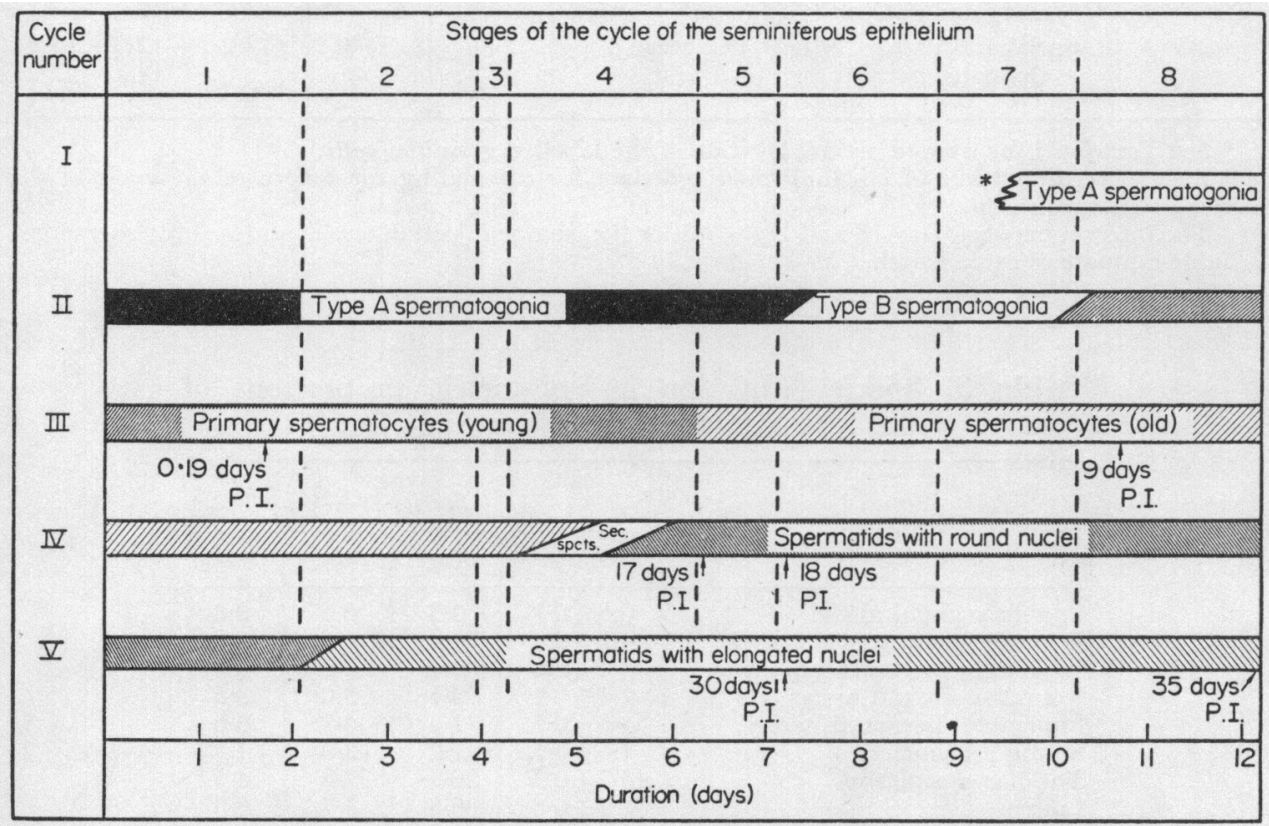

TEXT-FIG. 1. Diagram illustrating spermatogenesis in the stallion. About $4 \cdot 2$ cycles of the seminiferous epithelium are shown, and the durations (frequencies) of the eight stages composing each cycle are indicated. The width of the various columns is proportional to the duration of the stages. The most advanced labelled germinal cells at various intervals after injection are indicated by 'day P.I'. The asterisk indicates that the precise onset of spermatogenesis has not as yet been determined.

At $4 \frac{1}{2} \mathrm{hr}$ after $\left[{ }^{3} \mathrm{H}\right]$ thymidine was injected, leptotene primary spermatocytes in stage 1 were the most mature germinal cells labelled. As the time after isotopic injection increased, the most mature labelled germinal cells advanced until, at 35 days, labelled spermatozoa were leaving the testes (Text-fig. 1). 
Table 2. Estimates of the duration of one cycle of the seminiferous epithelium in the stallion

\begin{tabular}{|c|c|c|c|c|c|c|c|}
\hline \multirow{2}{*}{$\begin{array}{c}\text { Interval } \\
\text { after } \\
\text { injection } \\
\text { of } \\
\text { thymidine } \\
\text { (days) }\end{array}$} & \multicolumn{2}{|c|}{$\begin{array}{l}\text { Most advanced labelled } \\
\text { type of germinal cell }\end{array}$} & \multicolumn{2}{|c|}{$\begin{array}{c}\text { Interval since } \\
\text { labelling as } \\
\text { leptotene primary } \\
\text { spermatocytes }\end{array}$} & \multicolumn{3}{|c|}{$\begin{array}{c}\text { Duration of one cycle } \\
\text { (days) }\end{array}$} \\
\hline & Cell type & $\begin{array}{l}\text { Cycle and } \\
\text { stage* }\end{array}$ & $\begin{array}{c}\text { No. } \\
\text { of } \\
\text { cycles } \\
\text { traversed }\end{array}$ & $\begin{array}{c}\text { Time } \\
\text { (days) }\end{array}$ & $\begin{array}{l}\text { Based on } \\
\text { initial } \\
\text { point of } \\
\text { labelling }\end{array}$ & $\begin{array}{r}\text { Bas } \\
\text { inter } \\
\text { poir } \\
\text { labe }\end{array}$ & $\begin{array}{l}\text { d on } \\
\text { diate } \\
\text { sof } \\
\text { ing }\end{array}$ \\
\hline $0 \cdot 2$ & $\begin{array}{l}\text { Primary spermato- } \\
\text { cyte (leptotene) }\end{array}$ & III, late stage I & & & & & \\
\hline 9 & $\begin{array}{l}\text { Primary spermato- } \\
\text { cyte (pachytene) }\end{array}$ & III, early stage 8 & 0.74 & $8 \cdot 8$ & $11 \cdot 9$ & & \\
\hline 17 & $\begin{array}{l}\text { Spermatid with } \\
\text { round nucleus }\end{array}$ & IV, early stage 5 & $1 \cdot 38$ & $16 \cdot 8$ & $12 \cdot 2$ & $12 \cdot 5$ & \\
\hline 18 & $\begin{array}{l}\text { Spermatid with } \\
\text { round nucleus }\end{array}$ & IV, early stage 6 & 1.45 & $17 \cdot 8$ & $12 \cdot 3$ & $12 \cdot 7$ & \\
\hline 30 & $\begin{array}{l}\text { Spermatid with } \\
\text { elongated nucleus }\end{array}$ & $V$, early stage 6 & $2 \cdot 45$ & $29 \cdot 8$ & $12 \cdot 2$ & $\begin{array}{l}12 \cdot 3 \\
12 \cdot 0\end{array}$ & $12 \cdot 1$ \\
\hline 35 & $\begin{array}{l}\text { Spermatid with } \\
\text { elongated nucleus }\end{array}$ & $V$, end stage 8 & $2 \cdot 86$ & $34 \cdot 8$ & $12 \cdot 2$ & $\begin{array}{l}12 \cdot 3 \\
12 \cdot 1\end{array}$ & $\begin{array}{l}12 \cdot 2 \\
12 \cdot 2\end{array}$ \\
\hline
\end{tabular}

* See Text-fig. 1 for a more precise location of the labelled germinal cells.

$\dagger$ Each preceding point of labelling provided data for calculating the length of the cycle of the seminiferous epithelium.

† The interval between Day 18 and Day 17 after the isotope injection was considered too short for a reliable estimate of cycle length.

Table 3. Species variation in volumetric proportions of testicular structures

\begin{tabular}{|c|c|c|c|c|}
\hline \multirow{2}{*}{ Structure } & \multicolumn{4}{|c|}{ Species } \\
\hline & Stallion & Boar* & Bull $\uparrow$ & Dog \\
\hline $\begin{array}{l}\text { Spermatogonial nuclei } \\
\text { Primary spermatocyte nuclei } \\
\text { Secondary spermatocyte nuclei } \\
\text { Round spermatid nuclei } \\
\text { Elongated spermatid nuclei } \\
\text { Sertoli cell nuclei } \\
\text { Tubular cytoplasm } \$ \\
\text { Lumen } \\
\text { Basement membrane } \\
\text { Intertubular space }\end{array}$ & $\begin{array}{r}0 \cdot 6 \pm 0 \cdot 1 \\
4 \cdot 2 \pm 0 \cdot 1 \\
0 \cdot 1 \pm 0 \cdot 0 \\
2 \cdot 1 \pm 0 \cdot 1 \\
1 \cdot 0 \pm 0 \cdot 1 \\
1 \cdot 6 \pm 0 \cdot 1 \\
45 \cdot 7 \pm 0 \cdot 5 \\
3 \cdot 4 \pm 0 \cdot 3 \\
2 \cdot 6 \pm 0 \cdot 1 \\
38 \cdot 7 \pm 0.5\end{array}$ & $\begin{array}{r}0 \cdot 3 \\
4 \cdot 8 \\
0 \cdot 1 \\
3 \cdot 1 \\
1 \cdot 6 \\
1 \cdot 2 \\
56 \cdot 7 \\
6 \cdot 6 \\
2 \cdot 8 \\
22 \cdot 7\end{array}$ & $\begin{array}{r}0.6 \\
4 \cdot 6 \\
0.2 \\
3 \cdot 0 \\
0 \cdot 9 \\
2 \cdot 0 \\
57 \cdot 8 \\
4 \cdot 7 \\
2 \cdot 6 \\
23 \cdot 6\end{array}$ & $\begin{array}{r}0.8 \\
6.6 \\
0 \cdot 1 \\
3.5 \\
0.8 \\
1.5 \\
64.7 \\
2.5 \\
2.8 \\
16.5\end{array}$ \\
\hline $\begin{array}{l}\text { Volume of seminiferous tubules } \\
\text { in testis }\end{array}$ & $61 \cdot 3 \pm 0.5$ & $77 \cdot 3$ & $76 \cdot 4$ & 83.5 \\
\hline
\end{tabular}

Values are means \pm S.E. $(\%)$.

* E. E. Swierstra, unpublished data.

$\uparrow$ Swierstra (1966).

$\mp$ E. E. Swierstra and C. J. Eagan, unpublished data.

$\S$ Non-nuclear area within a tubule stained by the PAS-haem technique was classified as tubular cytoplasm. 
On Day $35,6 \%$ and $34 \%$ of the spermatozoa in the right and left caput epididymidis, respectively, of Stallion 6 were labelled, and $5 \%$ in the left caput epididymidis of Stallion 5.

The mean duration of one cycle of the seminiferous epithelium, based on the progress of the most advanced labelled germinal cells was 12.2 (S.E. $\pm 0 \cdot 1$ ) days (Table 2). The life-span of primary spermatocytes was 19.0 days, of secondary spermatocytes was 0.7 days, of spermatids with round nuclei was $8 \cdot 7$ days, and of spermatids with elongated nuclei was $10 \cdot 1$ days.

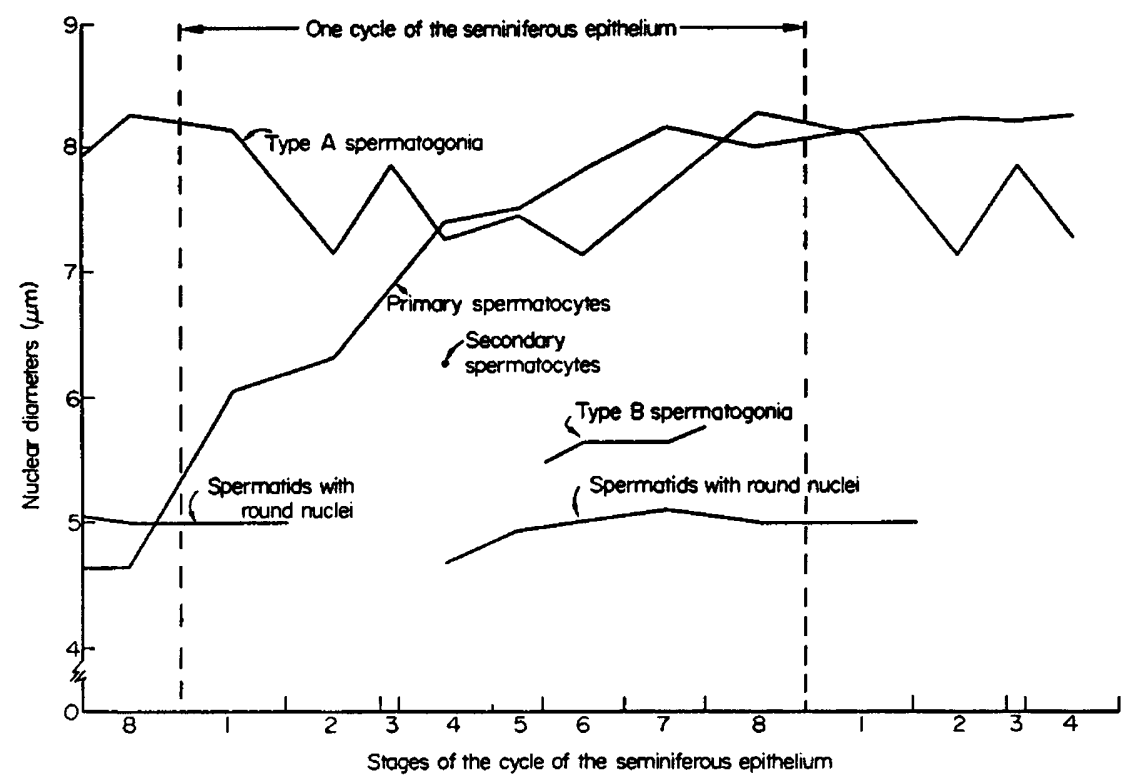

TEXT-FIG. 2. Nuclear diameters of the spermatogenic cells during the eight stages of the seminiferous epithelium in the stallion. Fourteen nuclei of each cell type were measured per stage. More than one cycle of the seminiferous epithelium is depicted in order to show the gradual changes in primary spermatocyte nuclei from the time they are formed (stage 8) until they give rise to secondary spermatocytes (stage 4). See also Text-fig. 1.

\section{Testicular composition}

In Exp. 1, the two groups of stallions killed at different times of the year did not differ significantly with respect to structural composition of the testes except for the percentage of primary spermatocyte nuclei (Table 3 ). The testes of stallions killed in December had $12.5 \%$ more primary spermatocyte nuclei $(\mathrm{v} / \mathrm{v})$ than those of stallions killed in September $(4.5$ versus $4.0 \%)$. There was a significant difference among stallions with respect to all the testicular structures measured except the volume percentage of intertubular space. By contrast, testes within stallions were similar in structural composition.

\section{Nuclear sizes, tubular diameters and tubular lengths}

The nuclear sizes of the different types of spermatogenic cells during the eight stages are shown in Text-fig. 2. Primary spermatocyte nuclei increased in volume as they matured from preleptotene to diplotene. Round spermatid 
nuclei increased rapidly in size after being formed in stage 4 and then underwent little change until elongation.

The diameters of the seminiferous tubules did not vary significantly among the eight stages or between the two groups of stallions in Exp. 1. Mean tubular diameters ( \pm S.E.) for stages 1 to 8 were $156 \pm 3,160 \pm 3,157 \pm 3,159 \pm 2$, $160 \pm 3,160 \pm 2,162 \pm 3$ and $161 \pm 2 \mu \mathrm{m}$, respectively. These values are actual measurements and are not corrected for histological shrinkage. Stallions within groups varied $(P<0.01)$ with respect to tubular diameters. Tubular length ranged from 1667 to $3726 \mathrm{~m}$ per testis, with a mean of $2419 \mathrm{~m}$ (Table 4).

Table 4. Testis, tunica albuginea and epididymal weights, and length of seminiferous tubules in stallions (Exp. 1)

\begin{tabular}{l|c}
\hline \multicolumn{1}{c|}{ Characteristic } & Mean \pm S.E. \\
\hline Testicular weight $(\mathrm{g})$ & $163 \pm 8$ \\
Tunica albuginea weight $(\mathrm{g})$ & $20 \pm 1$ \\
Epididymal weight $(\mathrm{g})$ & $25 \pm 1$ \\
Volume of tubules/testis $(\%)$ & $61 \pm 1$ \\
Length of tubules/testis (m) & $2419 \pm 113$ \\
Length of tubules/g of net testis weight* (m) & $17 \cdot 0 \pm 0 \cdot 1$ \\
\hline
\end{tabular}

* Net testis weight $=$ gross testis weight minus the weight of the tunica albuginea.

\section{DISGUSSION}

In stallions, as in most other mammals, the entire cross-section of any one seminiferous tubule is occupied by a single cellular association or stage (Perey, Clermont \& Leblond, 1961; Roosen-Runge, 1962; Hochereau, 1963a; Swierstra, 1968a; Ortavant et al., 1969). By contrast, tubular cross-sections in man are occupied by a number of different cellular associations (Clermont, 1963).

The frequencies of the stages differed from those in rats (Roosen-Runge \& Giesel, 1950; Hochereau, 1963b), rabbits (Swierstra \& Foote, 1963), rams (Ortavant et al., 1969), boars (Swierstra, 1968a), dogs (Foote et al., 1972) and bulls (Amann, 1962; Hochereau, 1963b). All of these researchers used the same system of classification of the stages, except that in certain cases the delineation between stages 5 and 6 differed slightly. The sum of frequencies for stages 5 and 6 , however, would be comparable for all studies. The observations on the stallion support the view that the relative frequencies of the stages are species-specific and that within a species the frequencies are relatively constant. There was more variation with respect to stage frequencies in stallions, however, than in rats, bulls, boars and dogs. Testes within stallions and locations within testes generally did not differ as to stage frequencies. Other researchers have found essentially no difference among locations within the testes of the bull (Amann, 1962; Hochereau, 1963b; Swierstra, 1966), boar (Kennelly \& Foote, 1964) and man (Roosen-Runge, 1956). The large variation among areas within locations may have been due to strongly coiled seminiferous tubules and, as a result, many tubules were in the same stage in a given area of a histological section (Hochereau, 1963a). From the analyses of the cell popula- 
tions making up the eight stages, it became evident that the stallion was similar to the boar and dog in that type B spermatogonia divided at the beginning of stage 8 to form primary spermatocytes (Swierstra, 1968a; Foote et al., 1972). By contrast, type B spermatogonia divide early in stage 1 in the bull and ram (Ortavant et al., 1969).

The autoradiographs from the testes of the first three stallions injected with $\left[{ }^{3} \mathrm{H}\right]$ thymidine were analysed before injecting isotope in the other three stallions. This procedure made it possible to select intervals from injection to castration for these last three stallions in such a way that the most advanced labelled germinal cells were at points during spermatogenesis where they could be most accurately localized. For instance, it became evident that labelled spermatozoa should be leaving the testes 35 days after injection. Three testes were therefore removed on that day and various percentages of labelled spermatozoa were found in the proximal portions of the caput epididymidis. Similarly, Amann, Koefoed-Johnson \& Levi (1965) reported that the percentage of labelled spermatozoa in the proximal caput epididymidis varied among and within rabbits.

The duration of the cycle of the seminiferous epithelium was $12 \cdot 2$ days. Cycle lengths for other species range from 8.6 days in the mouse and boar to 16 days in man when $\left[{ }^{3} \mathrm{H}\right]$ thymidine was used (see review by Clermont, 1972). In the stallion, the duration of the entire process of spermatogenesis can only be approximated because the scheme for spermatogonial divisions has not been determined. Until the exact time of the initial spermatogonial stem cell mitoses is known, it is assumed that spermatogenesis of stallions extends over four consecutive cycles of the seminiferous epithelium (Clermont, 1972). Based on this assumption, 49 days may be considered a reasonable approximation of the average duration of spermatogenesis in stallions.

The frequency of the stages and structural composition of the testes did not differ significantly between the groups of stallions killed in September and December, except for the larger volume of primary spermatocyte nuclei for those killed in December. At a later date, this could result in a larger number of spermatids and spermatozoa and could account for the increase in sperm output during the breeding season in late winter and spring (Pickett $e t$ al., 1970), but the hypothesis has yet to be tested. The observed difference in percentage of primary spermatocyte nuclei between the two groups may have been due to chance, since both groups of stallions were similar with respect to all other testicular structures.

The nuclear morphology of the cell types in the eight stages was similar to that of other mammals (Swierstra, 1968a; Courot, Hochereau-de Reviers \& Ortavant, 1970; Foote et al., 1972).

The nuclear sizes of the spermatogenic cells and their concomitant changes were similar to those of the rabbit, boar and dog (Swierstra \& Foote, 1963; Swierstra, 1968b; Foote et al., 1972). The seminiferous tubules comprised $61.3 \%$ of the stallion's testicular volume. This percentage was less than that reported for other species (Bascom \& Osterud, 1925; Amann, 1962). The diameters of the seminiferous tubules were smaller than those of other species (Bascom \& Osterud, 1925; Amann, 1962; Swierstra, 1966; Foote et al., 1972). 
Tubular diameters did not differ among stages. Amann (1962) made a similar observation with respect to the tubular diameters in the bull. By contrast, Roosen-Runge (1955) reported that, in the rat, tubular diameters increased during the later stages of the cycle of the seminiferous epithelium. The total tubular length of the stallion was calculated at $17.0 \mathrm{~m}$ per $\mathrm{g}$ of testicular tissue. The tunica albuginea comprised $12.3 \%$ of the total testicular weight and was excluded in calculating the length of the seminiferous tubule per $\mathrm{g}$ of testis.

\section{ACKNOWLEDGMENTS}

This research was supported in part by grants-in-aid from American Breeders Service; Cryenco, Cryogenic Engineering Co.; Eastern Artificial Insemination Cooperative, Inc.; and the National Association of Animal Breeders. The authors gratefully acknowledge the technical assistance of Mr H. H. S. Bell and Mr W. D. Sutherland.

\section{REFERENCES}

Amann, R. P. (1962) Reproductive capacity of dairy bulls. III. The effect of ejaculation frequency, unilateral vasectomy, and age on spermatogenesis. Am. F. Anat. 110, 49.

Amann, R. P., Kozfoed-Johnson, H. H. \& Levi, H. (1965) Excretion pattern of labelled spermatozoa and the timing of spermatozoa formation and epididymal transit in rabbits injected with thymidine- ${ }^{3}$ H. F. Reprod. Fert. $10,169$.

Bascom, K. F. \& Osterud, H. L. (1925) Quantitative studies of the testicle. II. Pattern and total tubule length in the testicles of certain common mammals. Anat. Rec. 31, 159.

BéLANGER, L. F. (1961) Staining processed radioautographs. Stain Technol. 36, 313.

Chalkley, H. W. (1943) Method for the quantitative morphologic analysis of tissues. F. natn. Cancer Inst. 4, 47.

Clermont, Y. (1963) The cycle of the seminiferous epithelium in man. Am. F. Anat. 112, 35.

GLERMONT, Y. (1972) Kinetics of spermatogenesis in mammals: seminiferous epithelium cycle and spermatogonial renewal. Physiol. Rev. 52, 198.

Courot, M., Hochereau-de Reviers, M. T. \& Ortavant, R. (1970) Spermatogenesis. In The Testis, Vol. I, p. 339. Eds. A. D. Johnson, W. R. Gomes and N. L. VanDemark. Academic Press New York and London.

Foote, R. H., Swierstra, E. E. \& Hunt, W. L. (1972) Spermatogenesis in the dog. Anat. Rec. 173, 341.

Gebauer, M. R. (1973) Extra-gonadal transit time, sperm production and sperm reserves in the stallion. Ph.D. thesis, Colorado State University.

Grer, H. T. \& Marion, G. B. (1970) Development of the mammalian testis. In The Testis, Vol. I, p. 1. Eds. A. D. Johnson, W. R. Gomes and N. L. VanDemark. Academic Press, New York and London.

Gray, P. (1958) Handbook of Basic Microtechnique, 2nd edn, p. 74. McGraw-Hill, New York.

Hochereau, M. T. (1963a) Etude comparée de la vague spermatogénétique chez le taureau et chez le rat. Annls Biol. anim. Biochem. Biophys. 3, 5.

Hochereau, M. T. (1963b) Constance des fréquences relatives des stades du cycle de l'épithélium séminifère chez le taureau et chez le rat. Annls Biol. anim. Biochem. Biophys. 3, 93.

KenNelly, J. J. \& Foote, R. H. (1964) Sampling boar testes to study spermatogenesis quantitatively and to predict sperm production. F. Anim. Sci. 23, 160.

Leblond, C. P. \& Clermont, Y. (1952) Definitions of the stages of the cycle of the seminiferous epithelium in the rat. Ann. N.Y. Acad. Sci. 55, 548.

MASUI, K. (1919) The spermatogenesis of domestic mammals. I. The spermatogenesis of the horse (Equus caballus). F. Coll. Agric. imp. Univ. Tokyo, 3, 357.

Nishrikawa, Y. (1959) Studies on Reproduction in Horses. Japan Racing Association, Shiba Tamuracho, Minatoku, Tokyo, Japan.

Ortavant, R., Courot, M. \& Hochereau, M. T. (1969) Spermatogenesis and morphology of the spermatozoon. In Reproduction in Domestic Animals, 2nd edn, p. 251. Eds. H. H. Gole and P. T. Cupps. Academic Press, New York and London.

Perey, B., Clermont, Y. \& Leblond, C. P. (1961) The wave of the seminiferous epithelium in the rat. Am. 7. Anat. 108, 47. 
Pickett, B. W., Faulkner, L. C. \& Sutherland, T. M. (1970) Effect of month and stallion on seminal characteristics and sexual behavior. F. Anim. Sci. 31, 713 .

Roosen-Runge, E. G. (1955) Quantitative studies on spermatogenesis in the albino rat. III. Volume changes in the cells of the seminiferous tubules. Anat. Rec. 123, 385.

Roosen-Runge, E. C. (1956) Quantitative investigations on human testicular biopsies. I. Normal testis. Fert. Steril. 7, 251.

Roosen-Runge, E. C. (1962) The process of spermatogenesis in mammals. Biol. Rev. 37, 343.

Roosen-Runge, E. C. \& Giesel, L. O. (1950) Quantitative studies on spermatogenesis in the albino rat. Am. F. Anat. 87, 1.

Skinner, J. D. \& Bowen, J. (1968) Puberty in the Welsh stallion. 7. Reprod. Fert. 16, 133.

Swrerstra, E. E. (1966) Structural composition of Shorthorn bull testes and daily spermatozoa production as determined by quantitative testicular histology. Can. J. Anim. Sci. 46, 107.

Swierstra, E. E. (1968a) Cytology and duration of the cycle of the seminiferous epithelium of the boar; duration of spermatozoan transit through the epididymis. Anat. Rec. 161, 171.

Swierstra, E. E. (1968b) A comparison of spermatozoa production and spermatozoa output of Yorkshire and Lacombe boars. F. Reprod. Fert. 17, 459.

Swierstra, E. E. \& Foote, R. H. (1963) Cytology and kinetics of spermatogenesis in the rabbit. $\mathcal{F}$. Reprod. Fert. 5, 309. 